\title{
Nerve Growth Factor-Dependence of Herpes Simplex Virus Latency in Peripheral Sympathetic and Sensory Neurons in vitro
}

\author{
C. L. Wilcox, ${ }^{1}$ R. L. Smith, ${ }^{2}$ C. R. Freed, ${ }^{3}$ and E. M. Johnson, Jr. ${ }^{4}$ \\ 'Departments of Microbiology and Immunology, ${ }^{2}$ Pediatrics, and ${ }^{3} \mathrm{Clinical}$ Pharmacology, University of Colorado Health \\ Sciences Center, Denver, Colorado 80262, and ${ }^{4}$ Department of Pharmacology, Washington University, St. Louis, \\ Missouri 63110
}

\begin{abstract}
Previously, we reported that nerve growth factor (NGF) is required to maintain herpes simplex virus (HSV) latency in cultures of rat sympathetic neurons (Wilcox and Johnson, 1987, 1988). Here, we extend these results by showing that NGF was also required to maintain HSV latency in cultures of sensory neurons obtained from dorsal root ganglia of rats, monkeys, and humans. The interruption of the neuronal supply of NGF for $1 \mathrm{hr}$ reactivated HSV, indicating that the latent virus was exquisitely sensitive to perturbations in the concentration or binding of NGF. A species-specific monoclonal antibody directed against the human NGF-receptor, which blocks NGF binding, reactivated latent HSV in human, but not rat, sensory neurons. In contrast, a monoclonal antibody against the rat NGF-receptor, which binds the receptor without blocking NGF action, did not produce reactivation. These results indicate that the effects of NGF on HSV latency are mediated via NGF binding to the NGF receptor. In addition, treatments that interfere with specific steps in the transduction of the NGF signal, including treatment with 6-hydroxydopamine and colchicine, reactivated latent HSV. Further, in neurons harboring latent virus, interruption of protein synthesis or RNA transcription for $1 \mathrm{hr}$ resulted in viral reactivation, suggesting that a short-lived factor may be present in neurons which represses viral reactivation.
\end{abstract}

Herpes simplex virus (HSV) is responsible for diseases in humans ranging in severity from subclinical infection to lethal encephalitis. The most common human illnesses caused by HSV are the recurrent common cold sore and genital herpes. Lesions occur following recrudescence of latent virus harbored in the sensory neurons innervating the involved epithelium. Both clinical and experimental studies show that damage to the neuronal target or to the nerve terminals results in reactivation of latent HSV (Carton and Kilbourne, 1952; Cook et al., 1974; Hill et al., 1978; Price and Schmitz, 1978; Sekizawa et al., 1980; Price, 1986; Tenser et al., 1988; Walz et al., 1974), suggesting that the neuronal target tissue produces a factor, or factors, which is

\footnotetext{
Received June 8, 1989; revised Sept. 11, 1989; accepted Oct. 23, 1989.

We thank Dr. L. I. Pizer for helpful discussion and support; P. A. K. Osborne for expert technical and editorial assistance. This work was supported in part by National Institutes of Health grants HL 20604 to E.M.J., NS 23918 to C.R.F., AG 07347 and AI 21402 to L. I. Pizer, Training Grant T32 NS 07321, and by a grant from the Monsanto Corporation to E.M.J.

Correspondence should be addressed to Christine L. Wilcox, Department of Microbiology and Immunology, Campus Box B175, University of Colorado Health Sciences Center, 4200 East Ninth Avenue, Denver, CO 80262.

Copyright (C) 1990 Society for Neuroscience $0270-6474 / 90 / 041268-08 \$ 02.00 / 0$
}

required for the maintenance of HSV latency. The clearly demonstrated sites of HSV latency are neural crest-derived sympathetic and sensory neurons (Stevens and Cook, 1971; Bastian et al., 1972; Baringer and Swoveland, 1973; Plummer, 1973; Cook et al., 1974; Walz et al., 1974; Price et al., 1975; Kennedy et al., 1983; Price, 1986), which are dependent upon nerve growth factor (NGF) for survival and function (Thoenen and Barde, 1980). NGF is produced and released in small quantities by the neuronal target tissue (Bandtlow et al., 1987).

Based on these observations, we recently examined the role of NGF in HSV infections of sympathetic neurons in vitro. We demonstrated that NGF is required to maintain latent infections of HSV-1 and HSV-2 in rat sympathetic neurons in culture (Wilcox and Johnson, 1987, 1988). Neuronal cultures are inoculated with HSV and maintained in the presence of NGF. Treatment with the antiviral drug, acyclovir (ACV), for 1 week after inoculation with virus allows a high multiplicity of infection to be utilized. Infection with approximately 5 plaque-forming units of either HSV-1 or HSV-2 per neuron results in the establishment of latency in essentially all of the neurons. Cultures harboring latent virus, maintained in the presence of NGF, do not express viral antigens, exhibit normal morphology, and have no detectable infectious virus either in culture supernatants or in association with cells when assayed after lysis (Wilcox and Johnson, 1988). Cultures are readily maintained for at least 5 weeks after inoculation without evidence of reactivation. Upon removal of NGF, viral antigens are detected within $24 \mathrm{hr}$ in virtually $100 \%$ of the neurons; neurons develop cytopathology and infectious virus is generally present $48-72 \mathrm{hr}$ after removal of NGF.

In this report we demonstrate NGF dependence of HSV latency in sensory neurons. Although latent HSV has been found in the human superior cervical ganglia (Warren et al., 1978), the major clinical reservoirs are the sensory ganglia, trigeminal ganglia and dorsal root ganglia (DRG) (Bastian et al., 1972; Baringer and Swoveland, 1973; Plummer, 1973). Our initial study of in vitro HSV latency is in the rat superior cervical ganglion (SCG) neurons. As the rat is not a natural host for HSV and because the sensory neuron is the major clinical reservoir, we were interested in determining if NGF-dependent HSV latency could be established in primate and rat sensory neurons in culture. In this paper we show that human, monkey, or rat DRG neurons responded similarly to the procedures used previously in rat SCG neurons, resulting in the establishment of latent HSV-1 infections with reactivation in response to NGF deprivation. NGF-dependent latency was demonstrated with 
HSV-1, as well as HSV-2, in rat DRG neuronal cultures. We report the further characterization of the NGF-dependent HSV latency in sympathetic and sensory neurons and discuss these results in the context of the known actions of NGF.

\section{Materials and Methods}

Preparation of viruses. HSV-1 (strain 115), a recent clinical isolate obtained from Charles Reed (Virology Laboratory, St. Louis Children's Hospital, St. Louis, MO), HSV-1 (KOS; L. I. Pizer), and HSV-2 (G; American Type Culture Collection, Rockville, MD) were used. Virus stocks were prepared by inoculating Vero cells (American Type Culture Collection) with a multiplicity of 0.1 ; cells were harvested approximately $48 \mathrm{hr}$ after inoculation when gross cytopathic effects were uniformly evident. Cell lysates, prepared by sonication of cells, were aliquoted and stored at $-70^{\circ} \mathrm{C}$. Viral titers were determined by the standard plaqueforming assay on Vero cells (Hsiung, 1982).

Neuronal cultures. Sympathetic neuronal cultures were prepared from SCG of prenatal rats as previously described (Wilcox and Johnson, 1987). Sensory neuronal cultures were prepared from DRG of several species: embryonic day 15 rats (Zivic-Miller Laboratories, Zelienople, PA); fetal, $19 \mathrm{~mm}$ crown-rump length Erythrorebus patas or Moccaca radiata monkeys (Primate Laboratory, UCHSC); and human fetuses $<10$ weeks gestation. Human fetal tissue was obtained by routine therapeutic abortion. The abortion procedure was not modified in any way except that sterile suction apparatus was used. Consent for use of fetal tissue for scientific purposes was obtained; there was no payment for the tissue.

Following dissection, the ganglia were enzymatically dissociated by incubation with $1 \mathrm{mg}$ collagenase (Boehring Mannheim, Indianapolis, IN) per ml of L-15 medium (GIBCO Laboratories, Grand Island, NY) for $30 \mathrm{~min}$ at $37^{\circ} \mathrm{C}$. After the incubation, ganglia were rinsed with L-15 medium containing $5 \%$ newborn bovine serum (GIBCO), mechanically dissociated in standard culture medium, and plated onto rat-tail collagen-coated, 24 well multidishes (Costar, Cambridge, MA). Standard culture medium used to maintain the neuronal cultures was Eagle's minimal essential medium (GIBCO) supplemented with $10 \%$ newborn bovine serum (GIBCO) and $50 \mathrm{ng} / \mathrm{ml} 2.5 \mathrm{~S}$ mouse NGF. The medium was replaced every 4-5 d. The neuronal cultures were treated with the antimitotic, fluorodeoxyuridine $(20 \mu \mathrm{M})$, for $7-10 \mathrm{~d}$ after plating to reduce the non-neuronal cell population. Based on cell counts from representative cultures after antimitotic treatment, cultures generally contained $1-5 \times 10^{4}$ neurons/well.

Establishment of latent $H S V$. Latently infected neuronal cultures were established as previously described (Wilcox and Johnson, 1987). Briefly, $7-12 \mathrm{~d}$ after preparing the cultures, $50 \mu \mathrm{M} \mathrm{ACV}$ (Burroughs Wellcome, Research Triangle Park, NC) was added to the cultures $12 \mathrm{hr}$ prior to inoculation with virus. Cultures were either mock-infected or infected with approximately 5 plaque-forming units of virus per neuron in the presence of ACV. Seven days after inoculation, the medium containing $\mathrm{ACV}$ was removed and replaced with standard culture medium. Fourteen days or longer after inoculation, culture supernatants were tested in plaque-forming assays to ensure that there was no evidence of active viral infection and then used in the studies described. Figure 1 shows the basic outline of the procedure for preparing the cultures.

Reactivation of latent HSV. From previous studies, we determined that the treatment protocol described above results in $100 \%$ of the SCG cultures surviving after infection with virus and $100 \%$ of the cultures harboring latent HSV (Wilcox and Johnson, 1988). Cultures with latent HSV were subjected to various treatments as described in the text and legends. Five days after the indicated treatment, cultures were evaluated for morphological evidence of HSV infection and were tested for the presence of infectious virus either by using cell lysates (prcparcd by sonicating the cells) or culture supernatants in plaque-forming assays. Morphological evidence of reactivation, neuritic fragmentation with hypertrophy of neuronal cell bodies, was generally concomitant with the detection of infectious virus. However, our criterion for reactivation of latent virus was the detection of infectious virus that, prior to treatment, was not present in the cultures. The results are expressed as the percentage of the cultures which reactivated after the treatment.

NGF binds nonspecifically to many substrates; consequently, unless otherwise indicated, antiserum to NGF was used to effect the rapid and complete removal of NGF. Antisera were produced by immunization of guinea pigs with mouse NGF as described by Rich et al. (1984). The sera were heat-inactivated to destroy complement and filter-sterilized.
NGF deprivation was produced by adding $1 \%$ anti-NGF serum [titers $>5000$, defined as the reciprocal of the highest dilution preventing neuritic outgrowth in the standard embryonic chicken DRG bioassay (Fenton, 1970)] to standard culture medium which lacked NGF. The addition of $1 \%$ nonimmune guinea pig serum in standard culture medium was used as a control.

Reagents. Chemicals were purchased from Sigma Chemical Co. (St. Louis, MO) unless otherwise indicated. Concentrations were as indicated in the legends of the tables and were prepared by dilution of concentrated stocks with standard culture medium. 6-Hydroxydopamine (6-OHDA) was prepared immediately prior to use in normal saline containing $1 \%$ ascorbic acid and diluted to the appropriate concentration with standard culture medium.

Cultures were exposed to ultraviolet (UV) irradiation as described (Martin et al., 1988) by using a UV-B lamp calibrated by the Department of Dermatology, Washington University School of Medicine (St. Louis, MO). Protein synthesis was determined as a function of ${ }^{35} \mathrm{~S}$-methionine incorporation as described by DiStefano et al. (1985).

\section{Results}

HSV latency in sensory neurons

Latent HSV has been demonstrated in human sympathetic ganglia (Warren et al., 1978); however, the predominant, clinically relevant sites of latent $\mathrm{HSV}$ are in sensory neurons of the trigeminal ganglia (Bastian et al., 1972; Baringer and Swoveland, 1973; Plummer, 1973; Price, 1986) and DRG (Price, 1986). Previously we demonstrated that HSV establishes latent infections in rat sympathetic neurons in vitro (Wilcox and Johnson, 1987,1988 ). Because of the relevance of HSV latency in peripheral sensory ganglia, we were interested in investigating the HSV infection in sensory neurons in culture. DRG neurons of similar fetal stages from rat, monkey, and human were prepared and maintained in tissue culture by the same methods as we had previously described for rat SCG neurons (outlined in Fig. 1). As in the rat SCG cultures (Wilcox and Johnson, 1988), inoculation of rat, monkey, or human DRG cultures with a multiplicity of infection of 5 plaque-forming units per cell of $\mathrm{HSV}-1$ in the presence of $50 \mu \mathrm{M}$ acyclovir (ACV) resulted in no evidence of viral damage or productive infection in the neurons. Removal of ACV after $7 \mathrm{~d}$ had no deleterious effects; cultures exhibited normal morphology and infectious virus was not detected in either culture supernatants or cell lysates (Table 1). The cultures were tested for the presence of latent virus by NGF deprivation. The data in Table 1 show that, in rat, monkey, and human DRG neuronal cultures, addition of anti-NGF serum resulted in uniform reactivation of virus. Simple removal of the NGF from the culture medium resulted in reactivation of latent HSV from rat DRG neuronal cultures, although with a delayed time course compared with the addition of anti-NGF antibodies (Table 1). The DRG neurons appeared to behave similar to rat sympathetic neurons, with the exception that in several experiments with rat DRG neuronal cultures reactivations occurred in $5 \%$ of the control cultures (Table 1).

To confirm that NGF deprivation was the critical event that produced reactivation, cultures of human and rat DRG neurons harboring latent virus were exposed to Mab-20.4, a speciesspecific anti-receptor monoclonal antibody which blocks NGF binding to the human NGF receptor but does not affect NGF binding to rat NGF receptors (Ross et al., 1984). Data in Table 1 show that Mab-20.4 produced reactivation in human, but not rat, DRG. A monclonal antibody directed against the rat NGF receptor, Mab-192, which binds to the NGF receptor without interfering with NGF binding or retrograde transport (Chandler et al., 1984; Taniuchi et al., 1985), did not produce reactivation when added to rat SCG neuronal cultures harboring latent HSV 
Superior cervical or dorsal root ganglia were removed from embryos, dissociated and cultured in standard medium containing $20 \mu \mathrm{M}$

fluorodeoxyuridine.

7-12 days

Fluorodeoxyuridine was removed from culture medium. Cultures were treated with $50 \mu \mathrm{M} \mathrm{ACV} 12 \mathrm{hrs}$ prior to inoculation with HSV. Cultures were maintained in the presence of standard medium containing $50 \mu \mathrm{M} \mathrm{ACV}$ after inoculation with HSV.

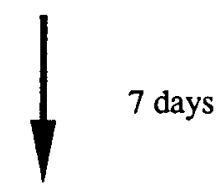

ACV was removed from culture medium.

Figure 1. Diagram of preparation neuronal cultures harboring latent HSV.

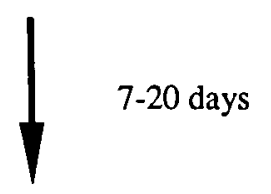

Cultures were used in the experiments described.
( 0 of 10 cultures). The effect of the anti-NGF antibodies may be via neutralization of free NGF or binding to NGF that is receptor bound, leading to cross-linking of receptors. However, since Mab-192, which recognizes rat NGF receptors without interfering with NGF binding, did not produce reactivation, the presence of an antibody in association with NGF receptors is not sufficient to cause reactivation. In addition, rat DRG neuronal cultures, deprived of NGF by simply replacing the culture medium with medium lacking NGF, produced reactivation (Table 1), indicating that NGF deprivation is the stimulus for reactivation.

The time course of the emergence of infectious virus and the appearance of the distinct cytopathology after NGF deprivation was examined in the cultures. A representative time course of reactivation from rat DRG neurons after NGF deprivation is shown in Figure 2. For both HSV-1 and HSV-2, infectious virus appeared between $48-72 \mathrm{hr}$ after the addition of anti-NGF serum. Characteristic cytopathic effects appeared with a similar time course. Similar results were obtained with human and monkey neurons (data not shown). These data suggest that NGF is required to maintain HSV in the latent state in neural crestderived sensory neurons, that the effects of NGF deprivation on viral latency are mediated via the NGF receptor, and that NGF-dependent HSV latency is not species specific.

Table 1. HSV latency in sensory neurons is dependent upon the presence of NGF

\begin{tabular}{|c|c|c|c|c|c|c|}
\hline \multirow[b]{3}{*}{ Source } & \multicolumn{6}{|c|}{$\%$ Reactivation (no. of positive cultures/no. tested) ${ }^{a}$ after treatment with: } \\
\hline & \multirow{2}{*}{$\begin{array}{l}\text { NGF removal }^{b} \\
\text { HSV-1 }\end{array}$} & \multicolumn{2}{|c|}{ Anti-NGF serum $^{c}$} & \multicolumn{2}{|c|}{ Nonimmune serum ${ }^{d}$} & \multirow{2}{*}{$\frac{\text { Mab-20.4e }}{\text { HSV-1 }}$} \\
\hline & & HSV-1 & HSV-2 & HSV-1 & HSV-2 & \\
\hline Rat DRG ${ }^{r}$ & $100(20 / 20)$ & $100(40 / 40)$ & $100(20 / 20)$ & $5(2 / 40)$ & $0(0 / 20)$ & $0(0 / 8)$ \\
\hline Monkey DRG & $\mathrm{ND}^{e}$ & $100(10 / 10)$ & ND & $0(0 / 10)$ & ND & ND \\
\hline Human DRG & ND & $100(20 / 20)$ & $\mathrm{ND}$ & $0(0 / 20)$ & ND & $100(20 / 20)$ \\
\hline
\end{tabular}

“ Neuronal cultures were infected with 5 pfu of HSV-1 (KOS) or HSV-2 (G), as indicated, per cell in the presence of 50 $\mu \mathrm{M}$ acyclovir. Two to three weeks postinoculation, cultures were treated as indicated. Cultures were tested for infectious virus by assaying cell lysates prepared by sonicating cells.

${ }^{b}$ Neuronal cultures were rinsed with 2 changes and then remained in standard culture medium lacking NGF.

c Neuronal cultures were treated with $1 \%$ anti-NGF serum in standard culture medium lacking NGF.

"Neuronal cultures were treated with $1 \%$ nonimmune serum in standard culture medium.

- Neuronal cultures were treated with $10 \mu \mathrm{g} / \mathrm{ml}$ of Mab-20.4, a species-specific monoclonal antibody directed against the human NGF receptor that blocks NGF binding (Ross et al., 1984).

Dorsal root ganglia.

${ }^{s}$ Not determined. 


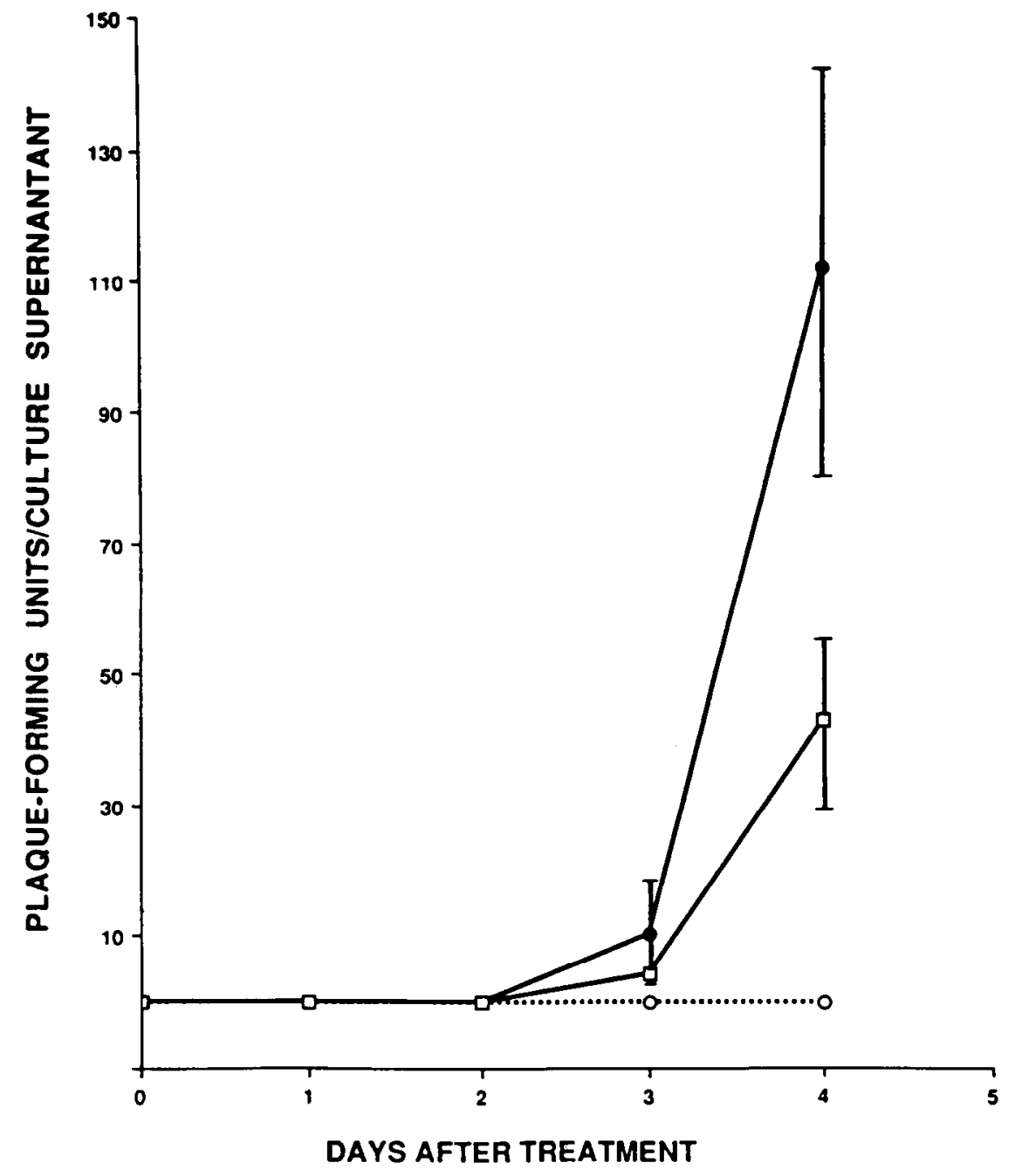

Figure 2. Expression of infectious virus during the course of reactivation of HSV- 1 and HSV-2 after NGF deprivation from rat DRG neuronal cultures. Neuronal cultures were inoculated with either 5 plaque-forming units of HSV-1 (KOS) or HSV-2 (G) per cell in the presence of $50 \mu \mathrm{M} A C V$. Two weeks after removal of ACV, the cultures were treated with either anti-NGF serum $(\longrightarrow-$ HSV-1-infected cultures; $\square \square$, HSV-2-infected cultures) or nonimmune serum $(--0--$, both HSV-1 and HSV-2 infected cultures). The culture supernatants were tested for infectious virus at $24 \mathrm{hr}$ intervals after the addition of immune or control serum. Results are expressed as the mean of the number of plaqueforming units recovered in the medium from 5 cultures per time point $( \pm S E M)$.

\section{Brief NGF deprivation reactivates latent virus}

To characterize further the apparent NGF dependence of HSV latency, we examined the duration of NGF deprivation that would result in reactivation of latent $\mathrm{HSV}$ from rat sympathetic and sensory neurons. Anti-NGF-containing medium or medium containing nonimmume serum was added to the cultures of neurons harboring latent virus and incubated for $1 \mathrm{hr}$. Thereafter, the cultures were rinsed 3 times and then remained in medium containing $500 \mathrm{ng} / \mathrm{ml} \mathrm{NGF}$, a 10-fold excess of the NGF concentration in standard medium, to ensure replacement of NGF. The effective removal of anti-NGF activitiy and subsequent replacement of NGF were documented by testing the culture supernatants in the chick DRG bioassay (data not shown). Deprivation of NGF for $1 \mathrm{hr}$ produced reactivation from rat SCG and DRG neuronal cultures, while the addition of $500 \mathrm{ng} /$ $\mathrm{ml} \mathrm{NGF}$, alone, or the addition of nonimmune serum did not result in reactivation of latent virus (Table 2 ). In mock-infected cultures, deprivation of NGF for $1 \mathrm{hr}$ did not produce any apparent morphological alterations or changes in the level of ${ }^{35} \mathrm{~S}$-methionine incorporation, suggesting that the overall level of protein synthesis was not affected (Martin et al., 1988). These results indicate that viral latency is extremely sensitive to a brief perturbation in the concentration or binding of NGF.
Treatment with 6-hydroxydopamine or colchicine reactivates latent $\mathrm{HSV}$

NGF signal transduction to the neuron is initiated by NGF binding to receptors that are localized in greatest concentration

Table 2. NGF deprivation for $1 \mathrm{hr}$ reactivates latent $\mathrm{HSV}$

$\%$ Reactivation from:

\begin{tabular}{ll}
\hline $\begin{array}{l}\text { Rat SCG neuronal } \\
\text { cultures }^{b} \text { (no. }\end{array}$ & $\begin{array}{l}\text { Rat DRG } \\
\text { neuronal cultures } \\
\text { (no. positive }\end{array}$ \\
cultures/no. tested) & $\begin{array}{l}\text { cultures/no. } \\
\text { tested) }\end{array}$ \\
\multicolumn{1}{c}{$0(0 / 22)$} & $0(0 / 22)$ \\
$100(32 / 32)$ & $100(20 / 20)$
\end{tabular}

${ }^{a} \%$ Nonimmune or anti-NGF serum was added to standard culture medium, removed after $1 \mathrm{hr}$, and replaced with medium containing $500 \mathrm{ng} / \mathrm{ml} \mathrm{NGF}$.

${ }^{b}$ Superior cervical ganglia (SCG) neuronal cultures were infected with 5 pfu of HSV-1 (strain 115) per cell in the presence of $50 \mu \mathrm{M}$ acyclovir. Two to three weeks postinoculation, cultures were treated as indicated. Cultures were tested for infectious virus by assaying culture supernatants as described in Materials and Methods.

c Dorsal root ganglia (DRG) neuronal cultures were prepared as described above for SCG cultures. 
Table 3. Drugs blocking NGF action reactivate latent $\mathrm{HSV}$

\begin{tabular}{llc} 
Treatment & Concentration & $\begin{array}{l}\text { \% Reactivation } \\
\text { (no. positive } \\
\text { cultures/no. tested) }\end{array}$ \\
\hline 6-Hydroxydopamine & $5 \mu \mathrm{g} / \mathrm{ml}$ & $100(12 / 12)$ \\
& $1 \mu \mathrm{g} / \mathrm{ml}$ & $100(12 / 12)$ \\
& $1 \mu \mathrm{g} / \mathrm{ml}+500 \mathrm{ng} / \mathrm{ml} \mathrm{NGF}$ & $100(12 / 12)$ \\
& $0.5 \mu \mathrm{g} / \mathrm{ml}$ & $100(12 / 12)$ \\
Colchicine & $0.5 \mu \mathrm{g} / \mathrm{ml}+500 \mathrm{ng} / \mathrm{ml} \mathrm{NGF}$ & $0(0 / 12)$ \\
& $0.1 \mathrm{~mm}$ & $100(12 / 12)$ \\
& $0.1 \mathrm{~mm}+500 \mathrm{ng} / \mathrm{ml} \mathrm{NGF}$ & $100(12 / 12)$
\end{tabular}

"Rat SCG neuronal cultures were infected with 5 pfu of HSV-1 (strain 115) per cell in the presence of $50 \mu \mathrm{m}$ acyclovir. Two to three weeks postinoculation, cultures were treated with the drug as indicated. Cultures were tested for infectious virus by assaying culture supernatants as described in Materials and Methods.

on the neurites. The receptor-bound NGF is then internalized; NGF (Hendry et al., 1974) and the NGF receptor (Johnson et al., 1987) are retrogradely transported to the neuronal soma. These processes have been well described in the context of NGF effects on neuronal function (Purves and $\mathrm{Nja}, 1976 ; \mathrm{Nja}$ and Purves, 1978; Johnson et al., 1979, 1987; Thoenen and Barde, 1980). 6-OHDA is a neural toxin that produces destruction of sympathetic nerve terminals (Thoenen, 1972). Under appropriate conditions, 6-OHDA produces selective destruction of sympathetic neurites, without apparent damage to the neuronal soma (Tiffany-Castiglioni and Perez-Polo, 1979). Therefore, we proposed that destruction of the neurites in the cultures would reduce the uptake of NGF and, thereby, result in the reactivation of latent virus. As shown in Table 3, addition of 6-OHDA at $0.5,1$, or $5 \mu \mathrm{g} / \mathrm{ml}$ produced reactivation of latent virus from SCG neurons. In contrast, treatment of rat sensory (DRG) neuronal cultures harboring latent $\mathrm{HSV}$ with $5 \mu \mathrm{g}$ of $6-\mathrm{OHDA} / \mathrm{ml}$ had no apparent affect on neuronal morphology or on viral latency ( 0 of 10 cultures produced infectious virus). At concentrations of 6-OHDA of 1 or $5 \mu \mathrm{g} / \mathrm{ml}$, fragmentation and degeneration of SCG neurites were observed within $24 \mathrm{hr}$ of treatment. Treatment of SCG neurons with $0.5 \mu \mathrm{g} / \mathrm{ml} \mathrm{6-OHDA} \mathrm{produced}$ reactivation of latent $\mathrm{HSV}$ but did not result in obvious damage to the neurites. The addition of a high concentration of NGF

Table 4. Inhibition of protein synthesis for $1 \mathrm{hr}$ reactivates latent HSV

\% Reactivation from:

\begin{tabular}{ll}
\hline Rat SCG & Rat DRG \\
neuronal & neuronal \\
cultures $^{a}$ & $\begin{array}{l}\text { cultures }^{a} \\
\text { (no. positive }\end{array}$ \\
(no. positive \\
cultures/no. & cultures/no. \\
tested) & tested) \\
\hline
\end{tabular}

Treatment

$100(40 / 40)$

$100(20 / 20)$

Cycloheximide

$(1 \mu \mathrm{g} / \mathrm{ml}, 1 \mathrm{hr})$

$100(20 / 20)$

$\mathrm{ND}^{b}$

Neuronal cultures were infected with 5 pfu of HSV-1 (KOS) per cell in the presence of $50 \mu \mathrm{M}$ acyclovir. Two to three weeks postinoculation, cultures were treated with the drug as indicated. Cultures were tested for infectious virus by assaying culture supernatants as described in Materials and Methods.

"Not determined.
$(500 \mathrm{ng} / \mathrm{ml})$ prevented reactivation produced by $0.5 \mu \mathrm{g} / \mathrm{ml}$ 6-OHDA. NGF was unable to prevent reactivation at the higher, more destructive, concentrations of $6-\mathrm{OHDA}$ ( 1 or $5 \mu \mathrm{g} / \mathrm{ml}$ ). These results suggest that $6-O H D A$ produced reactivation of latent HSV in sympathetic neurons as the result of NGF deprivation and are consistent with protective effects of high concentrations of NGF in preventing the toxic effects of 6-OHDA in vivo (Aloe et al., 1975) and in vitro (Tiffany-Castiglioni and Perez-Polo, 1979).

Colchicine, which inhibits microtubule polymerization, is proposed to block NGF action by interference with internalization and retrograde transport of NGF (Kreutzgerg, 1969; Johnson et al., 1979; Korsching and Thoenen, 1985). As shown in Table 3, colchicine reactivated latent HSV from rat SCG neuronal cultures even in the presence of high concentrations of NGF. However, colchicine treatment resulted in fragmentation of neurites in experimental, as well as control, neuronal cultures. Control cultures treated with colchicine underwent complete degeneration after $5 \mathrm{~d}$ of treatment. Since colchicine interferes with a wide range of cellular processes, the observed reactivation of latent HSV may be unrelated to NGF action. However, these results are consistent with reports indicating that colchicine treatment mimics the effects of NGF deprivation (Kreutzgerg, 1969; Johnson et al., 1979; Korsching and Thoenen, 1985).

${ }^{a}$ Rat superior cervical ganglia neuronal cultures were infected with 5 pfu of HSV-1 (strain 115) per cell in the presence of $50 \mu \mathrm{M}$ acyclovir. Two to three weeks postinoculation, cultures were treated as indicated. Cultures were tested for infectious virus by assaying culture supernatants as described in Materials and Methods.

${ }^{b}$ Protein synthesis was measured as described by DiStefano et al. (1985). 
Inhibition of protein synthesis or transcription reactivates latent $H S V$

To address the question of whether protein synthesis is required for reactivation of latent virus during the period of NGF deprivation, SCG neuronal cultures harboring latent HSV were exposed to anti-NGF serum for $1 \mathrm{hr}$ in the presence or absence of the protein synthesis inhibitor cycloheximide $(1 \mu \mathrm{g} / \mathrm{ml})$, which inhibits protein synthesis in these cultures $>90 \%$ (Martin et al., 1988). A set of cultures harboring latent virus was exposed only to cycloheximide. Surprisingly, brief exposure to cycloheximide alone resulted in reactivation of latent HSV-1. To examine the role of macromolecular synthesis on HSV latency, further cxpcriments were performed to examine the effects of inhibition of protein and mRNA synthesis; the results are shown in Table 4. When cultures of rat SCG or DRG neurons harboring latent virus were treated with cycloheximide in the presence of NGF for $1 \mathrm{hr}$, reactivation in $100 \%$ of the cultures was observed within 48-72 hr. No deleterious effects of $1 \mathrm{hr}$ of cycloheximide treatment on mock-infected cultures could be detected and complete reversal of inhibition of protein synthesis was observed (data not shown). Identical results were obtained when 5,6dicholoro-1-D-furanosylbenzimidazole (DRB), a reversible inhibitor of transcription (Mukherjee and Molloy, 1987), was added to cultures harboring latent virus for $1 \mathrm{hr}$ in the presence of NGF: $100 \%$ of the cultures developed cytopathology and produced infectious virus. These results suggest the presence of a short-lived factor, or factors, that acts to inhibit viral reactivation.

\section{$U V$ irradiation does not reactivate latent $H S V$}

The cultures used for the reactivation studies were well beyond the critical stage of NGF dependence for survival (Lindsay, 1988; Eichler and Rich, 1989); however, NGF deprivation in these cultures results in neuronal atrophy. Consequently, NGF deprivation may cause reactivation as the consequence of general injury. To test whether other, nonspecific, cell damage affected HSV latency, we examined the effects of UV irradiation on neuronal cultures harboring latent HSV. SCG neuronal cultures, which had been infected 2 weeks previously with HSV-1 as described in Materials and Methods, were exposed to a wide range of doses of UV irradiation: from a dose which caused no measurable effect on protein synthesis or cell survival, to a dose which produced complete inhibition of protein synthesis and cell lysis within $3 \mathrm{~d}$. Reactivation of latent HSV was not observed at any UV dose tested (Table 5). Irradiation at the higher doses $\left(22.5\right.$ and $\left.45.0 \mathrm{~nJ} / \mathrm{cm}^{2}\right)$ resulted in the rapid deterioration of the cultures, with complete cell degeneration on days 4 and 3 after irradiation, respectively. Cultures irradiated with 7.5 and $15 \mathrm{~nJ} / \mathrm{cm}^{2}$ appeared normal morphologically. In control cultures harvested at $3 \mathrm{~d}$ after irradiation with $15 \mathrm{~nJ} / \mathrm{cm}^{2}$, a transient decrease in ${ }^{35} \mathrm{~S}-$-methionine incorporation was observed. Two weeks after irradiation, the surviving cultures were treated with anti-NGF serum. All of these cultures produced infectious virus within $72 \mathrm{hr}$ of treatment. These results indicate that UV irradiation did not produce viral reactivation nor impair virus reactivation in response to NGF deprivation, indicating that not all forms of cell injury cause reactivation.

\section{Discussion}

$H S V$ latency in vitro

HSV infection of cells in culture, non-neuronal as well as neuronal cells, generally results in lytic destruction of the cells (Price,
1986). Exceptions include the establishment of persistently infected cultures, which produce defective virus (Levine et al., 1980), and an approach used by Wigdahl et al. $(1982,1983)$ of infecting neuronal or non-neuronal cells at elevated temperatures $\left(39.5-40.5^{\circ} \mathrm{C}\right)$ in the presence of an antiviral agent to suppress viral replication; subsequent lowering of the temperature and removal of the drugs or superinfection with cytomegalovirus results in HSV activation. Russell and Preston (1986) recently described an in vitro model which involves infection with a very low multiplicity of $\mathrm{HSV}-2$ at $42^{\circ} \mathrm{C}$, which suppresses virus replication; the infection is then stable with temperature shift to $37^{\circ} \mathrm{C}$. Activation is produced by superinfection with temperature-sensitive mutants of $\mathrm{HSV}-1$ or with cytomegalovirus.

Recently, we described a model that allows establishment of latent infections of either HSV-1 or HSV-2 in cultures of rat sympathetic neurons (Wilcox and Johnson, 1988). Using this system, we find that maintenance of HSV latency requires the presence of NGF. In this paper, we demonstrate that NGFdependent HSV latency was established in cultures of the clinically relevant sensory neurons from rat, monkey, or human dorsal root ganglia. These results are consistent with reports of HSV latency and reactivation from NGF-responsive, neural crest-derived neurons (Price, 1986; Thoenen and Barde, 1980). DRG sensory neurons both from the natural HSV host (human) and from rat and monkey behave very similarly to the previously characterized rat sympathetic neurons.

\section{Role of NGF in the maintenance of latent $H S V$}

The role of NGF in the maintenance of HSV latency was demonstrated by effecting NGF deprivation via several different mechanisms: NGF deprivation was produced by omitting NGF from the culture medium and by adding NGF-neutralizing antibodies; by the addition of a monoclonal antibody to the NGF receptor which blocks NGF binding; by treatment with the neurotoxin 6-OHDA, which produces damage to sympathetic nerve terminals; and by treatment with colchicine, which blocks retrograde axonal transport. Treatment of sympathetic neurons with 6-OHDA produces effects resembling NGF deprivation, related to destruction of the NGF-receptor-bearing nerve terminals. In vivo and in vitro, 6-OHDA treatment results in degenerative changes in sympathetic neurons, which can be prevented by administration of NGF (Johnson et al., 1979; Tiffany-Castiglioni and Perez-Polo, 1979). The results obtained in this study demonstrate that 6-OHDA, in doses that did not produce gross damage to the neurons, produced reactivation in cultures of sympathetic neurons harboring latent $\mathrm{HSV}$, and reactivation was prevented by addition of a high concentration of NGF. The ability of a high concentration of NGF to prevent reactivation caused by 6-OIIDA is consistent with the results of Campenot (1982), who demonstrated that NGF receptors on the cell soma are adequate to maintain neurons. These data suggest that 6-OHDA treatment of sympathetic neuronal cultures harboring latent HSV produced reactivation as the result of NGF deprivation. Colchicine treatment, however, interferes with a wide range of cellular processes involving microtubule-mediated functions. Internalization and retrograde transport of NGF are suggested to be essential steps in the NGF signal transduction (Thoenen and Barde, 1980); colchicine is likely to result in reactivation by preventing these essential steps. While NGF is apparently necessary to maintain latent HSV, the trigger which results in the reactivation, in some cases, may be a response to 
generalized cell damage, i.e., high doses of 6-OHDA. However, gross cell damage may not be sufficient, as not all forms of cellular injury resulted in reactivation of latent virus: UV irradiation over a wide range of doses did not reactivate latent HSV.

The observation that a brief interruption in the availability of NGF resulted in reactivation of latent HSV suggests that maintenance of HSV latency is exquisitely sensitive to cellular functions controlled by NGF. The cultures used for our studies were maintained in cell culture for at least 5 weeks, at which time the neurons no longer require NGF for survival, but do require NGF for maintenance of normal function (Lindsay, 1988; Eichler and Rich, 1989). In the mock-infected cultures, however, treatment with anti-NGF serum results in morphological changes consistent with NGF deprivation (Wilcox and Johnson, 1987). Previous work with cultures less than 2 weeks of age (Martin et al., 1988) has shown that NGF deprivation has no effects on protein synthesis or on cellular ultrastructure for at least $18 \mathrm{hr}$ after NGF deprivation and that the effects of NGF deprivation are completely reversible for at least $18 \mathrm{hr}$. It is of interest that a brief perturbation of NGF availability, which has no apparent adverse effects on cell morphology or viability, resulted in the uniform reactivation of latent $\mathrm{HSV}$. This exquisite sensitivity may be critical to the life cycle of the virus. The ability of the virus to respond to an early signal(s) produced by NGF deprivation, prior to significant cellular injury, may function to allow viral replication and reactivation prior to significant cell injury or cell death. This ability of the virus to respond to an early signal is consistent with the requirement of the virus to use host functions, such as protein synthetic apparatus and antegrade transport, to produce recrudescence in vivo. The virus would thereby be able to reactivate, replicate, and exit the neuron prior to the death of the host.

The nature of the NGF-dependent signal(s) which maintains latency or suppresses viral reactivation is not clear. However, the observation that even brief cessation of protein or mRNA synthesis resulted in reactivation is consistent with a model in which an NGF-mediated signal is responsible for the production or modification of a short-lived factor that acts to repress HSV reactivation. The data indicate that the in vitro model of HSV latency we have developed in rodent sympathetic and sensory neurons will provide a useful system in which to address the molecular mechanisms involved in the establishment and reactivation of latent HSV.

\section{References}

Aloe, L., E. Mugnaini, and R. Levi-Montalcini (1975) Light and electron microscopic studies of the cxccssive growth of sympathetic ganglia in rats injected daily from birth with 6-OHDA and NGF. Arch. Ital. Biol. 113: 236-353.

Bandtlow, C. E., R. Heumann, M. E. Schwab, and H. Thoenen (1987) Cellular localization of nerve growth factor synthesis by in situ hybridization. EMBO J. 6: 891-899.

Baringer, J. R., and P. Swoveland (1973) Recovery of herpes simplex virus from human trigeminal ganglions. N. Engl. J. Med. 288: 648650.

Bastian, F. O., A. S. Rabson, C. L. Yee, and T. S. Tralka (1972) Herpes hominis: Isolation from human trigeminal ganglions. Science 178 : 306-307.

Campenot, R. B. (1982) Development of sympathetic neurons in compartmentalized cultures. II. Local control of neurite survival by nerve growth factor. Dev. Biol. 93: 13-21.

Carton, C. A., and E. D. Kilbourne (1952) Activation of latent herpes simplex by trigeminal sensory-root section. N. Engl. J. Med. 246: 172-176.
Chandler, C. E., L. A. Parsons, M. Hosang, and E. M. Shooter (1984) A monoclonal antibody modulates the interaction of nerve growth factor with PC12 cells. J. Biol. Chem. 259: 6882-6889.

Cook, M. L., V. B. Bastone, and J. G. Stevens (1974) Evidence that neurons harbor latent simplex virus. Infect. Immunol. 9: 946-951.

DiStefano, P., J. Schweitzer, M. Taniuchi, and E. Johnson, Jr. (1985) Selective destruction of nerve growth factor receptor-bearing cells in vitro using a hybrid toxin composed of ricin $A$ chain and a monoclonal antibody against the nerve growth factor receptor. J. Cell Biol. 101: 1107-1114.

Eichler, M., and K. M. Rich (1989) Death of sensory ganglion neurons after acute withdrawal of nerve growth factor in dissociated cell culture. Brain Res. 482: 340-346.

Fenton, E. L. (1970) Tissue culture assay of nerve growth factor and of the specific antiserum. Exp. Cell. Res. 59: 383-392.

IIendry, I. A., K. Stockel, H. Thoenen, and L. L. Iverson (1974) The retrograde transport of nerve growth factor. Brain Res. 68: 103-121.

Hill, T. J., W. A. Blyth, and D. A. Harbour (1978) Trauma to the skin causes recurrence of herpes simplex virus in the mouse. J. Gen. Virol. 39: 21-28.

Hsiung, G. D. (1982) Diagnostic Virology, pp. 26-29, Yale University Press, New Haven, CT.

Johnson, E. M., Jr., R. A. Macia, R. Y. Andres, and R. A. Bradshaw (1979) The effects of drugs which destroy the sympathetic nervous system on the retrograde transport of nerve growth factor. Brain Res. 171: 461-472.

Johnson, E. M., Jr., M. Taniuchi, H. B. Clark, J. E. Springer, S. Koh, M. W. Tayrien, and R. Loy (1987) Demonstration of the retrograde transport of nerve growth factor receptor in the peripheral and central nervous system. J. Neurosci. 7: 923-929.

Kennedy, P. G. E., S. A. Al-Saadi, and G. B. Clemets (1983) Reactivation of latent herpes simplex virus from dissociated identified dorsal root ganglion cells in culture. J. Gen. Virol. 64: 1629-1635.

Korsching, S., and H. Thoenen (1985) Treatment with 6-hydroxydopamine and colchicine decreases nerve growth factor levels in sympathetic ganglia. J. Neurosci. 5:1058-1061.

Kreutzgerg, G. W. (1969) Neuronal dynamics and axonal flow. IV. Blockage of intra-axonal enzyme transport by colchicine. Proc. Natl. Acad. Sci. USA 62: 722-728.

Levine, M., A. L. Goldin, and J. C. Glorioso (1980) Persistence of herpes simplex virus genes in cells of neuronal origin. J. Virol. 35: 203-210.

Lindsay, R. M. (1988) Nerve growth factors (NGF, BDNF) enhance axonal regeneration but are not required for survival of adult sensory neurons. J. Neurosci. 8: 2394-2405.

Martin, D. P., R. E. Schmidt, P. S. DiStefano, O. H. Lowry, J. G. Carter, and E. M. Johnson, Jr. (1988) Inhibitors of protein synthesis and RNA synthesis prevent neuronal death caused by nerve growth factor deprivation. J. Cell Biol. 106: 829-844.

Mukherjee, R., and G. R. Molloy (1987) 5,6-Dicholor-1-D-ribofuranosylbenzimidazole inhibits transcription of the hemoglobin gene in vivo at initiation. J. Biol. Chem. 262: 13697-13705.

$\mathrm{Nja}, \mathrm{A}$., and $\mathrm{D}$. Purves (1978) The effects of nerve growth factor and its antiserum on synapses in the superior cervical ganglion of the guinea-pig. J. Physiol. (Lond.) 277: 53-75.

Plummer, G. (1973) Isolation of herpesviruses from trigeminal ganglia of man, monkeys, and cats. J. Infect. Dis. 128: 345-348.

Price, R. W. (1986) Neurobiology of human herpesvirus infections. CRC Crit. Rev. Clin. Neurobiol. 2: 61-123.

Price, R. W., and J. Schmitz (1978) Reactivation of latent herpes simplex virus infection of the autonomic nervous system by postganglionic neurectomy. Infect. Immun. 19: 523-532.

Price, R. W., B. J. Katz, and A. L. Notkins (1975) Latent infection of the peripheral ANS with herpes simplex virus. Nature 257:686-688.

Purves, D., and A. Nja (1976) Effects of nerve growth factor on synaptic depression following axotomy. Nature 260: 535-536.

Rich, K. M., H. K. Yip, P. A. Osborne, R. E. Schmidt, and E. M. Johnson, Jr. (1984) Role of nerve growth factor in the adult dorsal root neuron and its response to injury. J. Comp. Neurol. 230: 110 118.

Ross, A. H., P. Grob, M. Bothwell, D. E. Elder, C. S. Ernst, N. Marano, B. F. D. Ghrist, C. C. Slemp, M. IIerlyn, B. Atkinson, and H. Koprowski (1984) Characterization of nerve growth factor receptor in neural crest tumors using monoclonal antibodies. Proc. Natl. Acad. Sci. USA 81: $6681-6685$ 
Russell, J., and C. M. Preston (1986) An in vitro latency system for herpes simplex virus type 2. J. Gen. Virol. 67: 397-403.

Sekizawa, T., H. Openshaw, C. Wohlenberg, and A. L. Notkins (1980) Latency of herpes simplex virus in absence of neutralizing antibody: Model for reactivation. Science 210: 1026-1028.

Stevens, J. G., and M. L. Cook (1971) Latent herpes simplex virus in spinal ganglia of mice. Science 173: 843-845.

Taniuchi, M., and E. M. Johnson, Jr. (1985) Characterization of the binding properties and retrograde axonal transport of a monoclonal antibody directed against the rat nerve growth factor receptor. J. Cell Biol. 101: 1100-1 106.

Tenser, R. B., W. A. Edris, and K. A. Hay (1988) Herpes simplex virus latent infection: Reactivation and elimination of latency after neurectomy. Virology 167: 302-305.

Thoenen, H. (1972) Surgical immunological and chemical sympathectomy. In Handbook of Experimental Pharmacology, Vol. 33, $\mathrm{H}$. Blaschko and E. Muscholl, eds., pp. 813-844, Springer, Berlin.

Thoenen, H., and Y.-A. Barde (1980) Physiology of nerve growth factor. Physiol. Rev. 60: 1284-1335.

Tiffany-Castiglioni, and J. R. Perez-Polo (1979) The role of nerve growth factor in vitro cell resistance to 6-hydroxydopamine toxicity. Exp. Cell. Res. 121: 179-189.
Walz, M. A., R. W. Price, and A. L. Notkins (1974) Latent ganglionic infection with herpes simplex virus types 1 and 2: Viral reactivation in vitro after neurectomy. Science 184: 1185-1187.

Warren, K. G., S. M. Brown, Z. Wroblewska, D. Gilden, H. Koprowski, and J. Subak-Sharpe (1978) Isolation of latent herpes simplex virus from superior cervical and vagus ganglions of human beings. N. Engl. J. Med. 298: 1068-1069.

Wigdahl, B. L., A. C. Scheck, E. De Clercq, and F. Rapp (1982) High efficiency latency and activation of herpes simplex virus in human cells. Science 217: 1145-1146.

Wigdahl, B. L., R. J. Ziegler, M. Sneve, and F. Rapp (1983) Herpes simplex virus latency and reactivation in isolated rat sensory neurons. Virology 127: 159-167.

Wilcox, C. L., and E. M. Johnson, Jr. (1987) Nerve growth factor deprivation results in the reactivation of latent herpes simplex virus in vitro. J. Virol. 61: 2311-2315.

Wilcox, C. L., and E. M. Johnson, Jr. (1988) Characterization of nerve growth factor-dependent herpes simplex virus latency in neurons in vitro. J. Virol. 62: 393-399. 